\title{
THE IMPACT OF URBAN RENEWAL ON NEIGHBORING HOUSING PRICES: AN APPLICATION OF HIERARCHICAL LINEAR MODELING
}

\author{
Chun-Chang LEE ${ }^{1, *}$, Chih-Min LIANG ${ }^{2}$, Wen-Chih $\mathrm{YEH}^{3}$, Zheng YU 4 \\ ${ }^{1}$ Department of Real Estate Management, National Pingtung University, Pingtung, Taiwan \\ ${ }^{2}$ Department of Public Finance and Tax Administration, National Taipei University of Business, Taipei, Taiwan \\ ${ }^{3}$ Department of Real Estate Management, HungKuo Delin University of Technology, New Taipei, Taiwan \\ ${ }^{4}$ Department of Land Economics, National Chengchi University, Taipei, Taiwan
}

Received 24 May 2021; accepted 10 September 2021; first published online 17 January 2022

\begin{abstract}
This study explored the impacts of urban renewal projects on neighboring housing prices. Hierarchical linear modeling (HLM) was employed to analyze urban renewal projects in Taipei City. The Level 1 independent variables pertained to a house itself (19,157 pieces of data), such as its structure and neighborhood attributes. The Level 2 variable pertained to an urban renewal project (23 cases of urban renewal), and the explanatory variable was the scale of each urban renewal project. The study examined whether differences exist between the impacts of various urban renewal projects on neighboring housing prices, and analyzed the extent to which the differences in neighboring housing prices are caused by the differences between urban renewal projects. The empirical results showed that the mean housing price varies significantly between each urban renewal project. In regard to the variance in the mean house price, $31.46 \%$ was caused by the differences between the urban renewal projects. The estimated coefficient of the grand floor area of urban renewal (FLAREA) had a positive value and attained a $1 \%$ level of significance. This indicates that the larger the scale of an urban renewal project, the larger its effects on neighboring housing prices. The empirical results of this study could better explain the impacts of the scale of an urban renewal project on the externalities of urban renewal.
\end{abstract}

Keywords: urban renewal, housing prices, grand floor area, scale of an urban renewal project, hierarchical linear modelling.

\section{Introduction}

According to Article 4 of Taiwan's Urban Renewal Act, the primary objectives of urban renewal are to promote comprehensive environmental sustainability, improve the quality of living, and transform the appearance and aesthetics of a city. The process of urban renewal entails three approaches: reconstruction, renovation, and maintenance. In reconstruction, specific urban renewal areas are designated where the existence of worn-out houses could potentially impact their surrounding area, and these buildings are demolished on a large scale in order to enhance the quality of living and to promote the growth of housing prices in neighboring areas. In renovation and maintenance, houses that have a dilapidated exterior, a visually unappealing appearance, or a deteriorated functionality are subjected to small-scale renovations and facelifts to enhance their functionality and usage as well as to beautify the city they are found in.
With regard to the issue of urban renewal on housing prices, many studies have explored the impacts of urban renewal laws and provisions and analyzed the implementation of urban renewal projects. For instance, Jones (2008) and Hyra (2008) examined urban renewal and the post-war "new urban renewal" in the United States. Both authors focused on the racial differences and expounded unjust urban renewal projects by attaching importance to the process of community participation and the continuous development of housing prices. Some studies and data reviewers had analyzed the impacts of an urban renewal project on housing prices within the project area after its completion, and few had studied the impacts of urban renewal and reconstruction on housing prices in neighboring areas. In a recent study, Lee et al. (2017) investigated the impacts of urban renewal delineation time on housing prices in neighboring areas by employing the differencein-difference estimation approach. The empirical results

*Corresponding author. E-mail: lcc@mail.nptu.edu.tw 
indicated that housing prices per ping within the urban renewal area (the experimental group) were increased by NT\$11,320 after the delineation time. This increase indicates the value added on houses in neighboring areas after the implementation or urban renewal. Liang et al. (2020) examined the impacts of urban renewal on neighboring housing prices by combining the difference-in-difference approach and spatial econometrics, as well as taking into account the spatial dependence of neighboring houses. Their empirical findings showed that the estimated coefficient of the interaction variable of an 800-meter range and time of an urban renewal project in the renewal/review phase was 0.0752 and attained a $1 \%$ level of significance. This showed that for housing transactions completed within 800 meters of an urban renewal range and after urban renewal, housing prices had increased by $7.52 \%$ on average. On the other hand, the estimated coefficient of the interaction variable of an 800-meter range and time of an urban renewal project in the implementation/completion phase was 0.0309 and did not attain a level of significance. This showed that even though housing transactions completed within 800 meters of an urban renewal range and after urban renewal had increased neighboring housing prices, the impact was not statistically significant.

Nonetheless, Lee et al. (2017) and Liang et al. (2020) did not explore the impacts of an urban renewal project's intrinsic differences on neighboring housing prices, the impacts of the scale of urban renewal on neighboring housing prices, and the differences between these two kinds of impacts. Housing data are multilevel by nature, and the traditional hedonic pricing model generally uses the ordinary least squares (OLS) estimation approach, in which data with different hierarchical characteristics is confined to a single hierarchy for data processing. Since this approach does not consider the estimation of hierarchical problems, it is unable to break down the changes in housing prices at different spatial levels and may easily confound the house's locational characteristics with its structural attributes (Jones \& Bullen, 1994). Uyar and Brown (2007) concurred that a house is not just a single entity, and that each housing unit is nested within or belongs to a block, zone, school zone, and a town. Houses in the same neighborhood have similar attributes in terms of the neighborhood's geography, economy, environment, and society. Variables such as the natural environment, living environment, folk customs, economic status, and level of medical services in these neighborhoods or societies affect the samples and cause the residuals to violate the independence assumption of a model. Consequently, the estimated error variance is overestimated while the regression coefficient standard error is underestimated. In a similar vein, since housing units are nested within various urban renewal projects, the impacts of an urban renewal project on neighboring housing prices should take into account the intrinsic differences of the project on neighboring housing prices.

This study sought to explore the impacts of urban renewal and reconstruction projects on neighboring hous- ing prices after the completion of the projects. In Taiwan, most existing urban renewal projects are located in Taipei City. Nonetheless, this study explored the changes in housing prices affected by urban renewal projects nearby. Hierarchical linear modeling (HLM) was employed for data analysis. Compared to the conventional ordinary least squares (OLS) models, HLM can further illuminate the relationships between housing prices and the characteristics of urban renewal projects. The characteristics of an urban renewal project were represented by the project scale in this study, which sought to elucidate the differences of the impacts of various urban renewal projects in Taipei City on neighboring housing prices, as well as to analyze the extent to which the differences in neighboring housing prices are caused by the differences between urban renewal projects.

This study distinguishes itself from previous studies by using hierarchical linear modeling to examine the impacts of various urban renewal projects on neighboring housing prices. We expect that our findings can contribute to enhancing the quality of urban renewal-related studies.

This study consists of five sections: Section 1 offers a literature review of relevant theories and studies; Section 2 describes the methods and procedures used in this empirical research; Section 3 and 4 describes the sample and data collection, processing, and descriptive statistics; Section 5 presents and discusses the empirical results; and the last section lays out the conclusions and recommendations.

\section{Literature review}

Urban renewal is undoubtedly an issue of global concern, and its externalities are also emphasized by many scholars. Chau and Wong (2014) suggested that positive and negative externalities may exist concurrently in urban renewal. Positive externalities are produced because urban renewal can help refurbish dilapidated houses and reduce the negative externalities they pose to neighboring houses. On the other hand, negative externalities are produced because an urban renewal project would diminish the likelihood of renewal in surrounding areas. Since the specific process and implementation of urban renewal varies across countries, the positive and negative externalities exerted by urban renewal on neighboring housing prices would differ as well. For example, the empirical results obtained by Zheng et al. (2020) revealed that the significant and positive impacts brought by urban renewal on neighboring housing prices would persist for more than five years. Lai et al. (2018) opined that in government-led urban renewal Hong Kong aim to exploit private property rights. Nonetheless, the empirical results indicated the absence of positive externalities derived from urban renewal on neighboring houses.

The value of real estate increases in response to its surrounding landscape and environment as well as the appearance of special buildings. These values are related to the external benefits generated by urban renewal. Simons et al. (1998) surveyed housing prices following the deline- 
ation of an urban renewal area and revealed that housing prices located within one to two blocks from the renewal area had increased by US $\$ 677$. Jones (2008) studied urban development in England and stated that joint cooperation and community participation had improved the country's urban appearance during the period of post-war construction. Hyra (2008) studied the changing forms of communities in the US by segmenting different blocks, emphasizing urban afforestation, and conducting various urban community reconstructions, which resulted in housing price variation. Wang et al. (2013) noted that dilapidated houses in urban areas had to undergo reconstruction or renovation in order to increase their economic benefits, thus affecting the neighboring housing prices.

From 2008 to 2017, Nigeria actively promoted urban renewal through urban renewal plans in which 63 real estate and appraisal companies compiled city infrastructure and commercial property-related data. Research has shown that city infrastructure such as roads, sewerage systems, water supply systems, and waste treatment systems were upgraded through the urban renewal plans. From the perspective of emerging economies in Africa, these urban renewal plans have offered business opportunities for investors, who have invested in commercial property in droves, resulting in remarkable changes in the rental prices of local commercial property. In particular, the rental prices of commercial property adjacent to public transportation facilities have increased tenfold or more compared to pre-urban renewal prices. Given that these commercial interests are held by a handful of individuals, even though the public would enjoy a better quality of urban life after urban renewal, the high rental prices of commercial properties would limit the operations and applications of economic activities (Wang et al., 2013). In Tokyo, many urban areas have undergone urban renewal to prepare for the Olympics that was scheduled to be held in 2020. Conducted based on the perspectives of different stakeholders and participants and adopting development strategies rooted in public-private partnerships, a study on the effects of urban renewal on neighboring housing prices and residents' quality of life demonstrated that urban renewal would drastically increase the rental prices of areas that have undergone urban renewal. Furthermore, services provided by public infrastructure would become more diverse and accessible, which would drive a new wave of migration. Housing rental prices in renewal areas closer to the city center are considerably higher than those in suburban areas. In addition, places near public transportation systems offer more business services and convenience, which would attract middle class and upper class citizens and thereby create new business agglomeration models (Mori, 2017). The goal of urban renewal should be centered on creating a sustainable, livable, salubrious, and modern city. To this end, in order to prevent partiality among land owners, the local conditions and value of an urban renewal area should be evaluated in advance to confirm how much the properties in the area are worth.
Yalpir and Bayrak (2017) performed a valuation of real estate in urban renewal areas by utilizing 23 criteria that covered 1078 real estate properties in Uluirmak District, Meram Town, Konya Province, Turkey. The Cobb-Douglas hybrid regression model was used for analysis. The results revealed that land valuation should not be merely dependent on the area index, but should include analyses and research based on the criteria completed within a short time, such that all land owners can obtain more rights.

Previous studies have concurred that the continuous development of urban renewal and comprehensive land use planning can help decision-makers make the right decisions in terms of building maintenance (Wang et al., 2013). Chau et al. (2003) explored the impacts of a real estate refurbishment project in Hong Kong on market value and demonstrated that the refurbishment project could increase neighboring real estate prices by $9 \%$, which exceeded the cost of the refurbishment project. Yau et al. (2006) advocated that refurbished buildings are beneficial for increasing neighboring property prices, and the refurbishment of old buildings can reduce negative externalities, thus enhancing the overall aesthetics and housing quality. They also reported that refurbishment and maintenance projects had resulted in a $6.57 \%$ increase in neighboring property prices. Rosenthal (2008) investigated the decline of cities in the US as well as the scope and nature of their reconstruction efforts. The empirical findings demonstrated that the reconstruction of old housing buildings can help increase the positive externalities of neighboring areas and improve the quality of the local neighborhood environment. The study by Musakwa and Niekerk (2013) indicated that urban renewal in southwestern Stellenbosch, South Africa had changed the region's land use patterns and subsequently increased its commercial and industrial usage area by $28 \%$ and $8 \%$, respectively, in addition to $17 \%$ more office properties. However, urban renewal does not necessarily increase neighboring housing prices. For instance, Uitermark and Loopmans (2013) examined Belgium's urban renewal policies and pointed out that urban renewal had a negative impact on housing prices within the urban renewal influence range because the delineated renewal area was a community consisting of poor families. Since the local government had failed to implement holistic planning when investing in urban renewal activities, the area that was supposed to undergo urban renewal was not redeveloped according to plans and remained unchanged.

Recently, Lee et al. (2017) investigated the impacts of urban renewal delineation time on housing prices in neighboring areas by employing the difference-in-difference estimation approach. The empirical results indicated that housing prices per ping within the urban renewal area (the experimental group) were increased by NT $\$ 11,320$ after the delineation time. This increase indicates the value added to houses in neighboring areas after the implementation or urban renewal. Liang et al. (2020) examined the impacts of urban renewal on neighboring housing prices 
by combining the difference-in-difference approach and spatial econometrics, and took into account the spatial dependence of neighboring houses. Their empirical findings showed that the estimated coefficient of the interaction variable of an 800-meter range and time of an urban renewal project in the renewal/review phase was 0.0752 and attained a $1 \%$ level of significance. This shows that for housing transactions completed within 800 meters of an urban renewal range and after urban renewal, housing prices had increased by $7.52 \%$ on average. On the other hand, the estimated coefficient of the interaction variable of an 800-meter range and time of an urban renewal project in the implementation/completion phase was 0.0309 and did not attain a level of significance. This shows that even though housing transactions completed within 800 meters of an urban renewal range and after urban renewal had increased neighboring housing prices, the impact was not statistically significant.

For the reference about hierarchical linear modeling (HLM), Basu and Thibodeau (1998) consider that if the spatial autocorrelation in the error term is ignored, it would lead to the estimation bias of the hedonic model. This means the estimated coefficient will not be accurate and it will generate an incorrect conclusion. Brown and Uyar (2004) used HLM to study the effects of the characteristics of the house and neighborhood on housing prices. They used the house square footage as the variable for Level 1, and the distance to downtown as the variable for Level 2. The empirical result shows that the characteristics of the house and neighborhood have a significant effect on housing prices. Moreover, the characteristics of the neighborhood will also influence how the characteristics of the house affect housing prices. Arribas et al. (2016) applied hierarchical linear modeling on mass appraisals. In Level 1, they add in the attributes of the house, including area, number of bedrooms, number of bathrooms, and how many floors. In Level 2, they add in the attributes of the block, such as the age of the block, the number of apartments, and location. Compared to the ordinary least squares adopted by the traditional hedonic model, HLM apparently can make the estimation more accurate, lower the estimation bias, and increase the efficiency of the estimation. HLM considers the prices of houses in the same block as not independent of each other, so they will be affected by the attributes of the block. In his research on the effects of leisure and sport on housing prices, Lee (2010) used hierarchical linear modeling. He put housing attributes in level 1, such as area, age, and living space. In Level 2 he put the attributes of neighborhood environment (based on township) such as whether residents thought facilities for leisure and sport were satisfactory. His empirical results show that leisure and sport have significant effects on average housing prices and that they generate the need for very significant adjustments. This means the positive effects of the living space on housing prices will be affected by the moderate based on leisure and sport.

\section{Research method}

\subsection{Empirical model settings}

In this study, analyses and estimations through HLM were performed on urban renewal proposals approved by the Taipei City Government, so as to examine the differences between the housing prices in neighboring areas impacted by an urban renewal project. Do and Park (2018) stated that hierarchical linear modeling (HLM) is a complex form of OLS estimation. Chang et al. (2018) employed HLM to study the impacts of auditor tenure on auditor quality. They pointed out that previous studies had produced conflicting results because the authors of these studies have overlooked the nested properties of the data. For instance, nesting auditors under an audit company would lead to interrelations between observed values, and using OLS estimation would augment type I errors. Comparatively speaking, HLM has considerably better estimation efficiencies as it simultaneously analyzes the intergroup and intragroup relations of nested data.

In the field of education, Chien and $\mathrm{Wu}(2020)$ examined the impacts of students' perceived teacher unfairness on their science achievement by applying data (classified into country-level, school-level, and student-level) from 52 countries into a three-level HLM. The empirical results showed that perceived teacher unfairness had negative impacts on the students' science achievement. In their research on the factors influencing dropout among students, Pov et al. (2020) employed a two-level HLM model in which the first level consisted of student attributes (such as age, grade retention, degree of absenteeism, academic performance, academic expectations, and employment of tutors); while the second level consisted of school factors (such as learning environment, degree of teacher fairness, degree of teacher assistance, degree of teacher absenteeism, home to school distance, and the sufficiency of textbooks). The results demonstrated that grade retention, absenteeism rate, academic expectations, and employment of tutors had significant effects on student dropout. Chien and $\mathrm{Wu}(2020)$ also utilized HLM to investigate the factors affecting science teachers' application of technology-based assessment (TBA) to assess students' performance. The authors divided the data into two levels - the first comprised student-level factors such as their degree of TBA engagement and computer literacy; and the second comprised school-level factors such as teachers' intensity of TBA usage and computer experience. The results demonstrated that the students' degree of TBA engagement and computer literacy had complementary effects on teachers' willingness to use TBA, while the school-level variables had moderating effects.

In the field of transportation and land use, $\mathrm{Xu}$ et al. (2021) employed HLM to study the factors of cultivated land fragmentation. The first level consisted of townshiplevel variables including natural factors (latitude, slope, land area); economic factors (GDP, proportion of secondary industries); social factors (population density and land 
use intensity); and locational factors (road accessibility and distance to city center). The second level consisted of county-level variables. The township-level variables included similar natural factors, economic factors, and social factors, with the difference being the addition of urbanization rate as a locational factor. The empirical results revealed the existence of significant interactions between the county-level and township-level variables. Chen and Jou (2019) employed HLM to investigate the relationship between the traffic accident risk of private vehicles and public transportation. Individual factors were placed in the first level while city factors were placed in the second level. The empirical results indicated that expanding the length and daily frequency of a bus route can reduce the likelihood and frequency of accidents.

This study employed a two-level hierarchy linear model for data analysis. Housing attributes and urban renewal projects formed the first and second levels of the model, respectively. The range of influence of an urban renewal project is defined to be $800 \mathrm{~m}$. The dependent variable in this study was the logarithmic form of housing price $\left(\ln P_{i t}\right)$. By taking the logarithmic form of housing price as a dependent variable, data heterogeneity can be reduced and the housing price distribution is more likely to approach a normal distribution suitable for linear analysis (Zient et al., 2008). In Taiwan, the transaction of a house is often based on the total price agreed to between the buyer and the seller. Moreover, even though unit price is converted from the total price and area, the registration of a house's area in the Ministry of the Interior's database is inconsistent, as some owners had registered the area of their balconies or public infrastructure, while some had not. This explains why the basis for the estimation of unit price is inconsistent. Lastly, as the reviewer had pointed out, if we chose to use total price, we would only be estimating effects on the distribution of housing sizes, but consequently, we can also estimate effects on the distribution of housing ages or lots, and this will cause unclear interpretations. However, we also think that the use of unit prices has similar shortcomings. The independent variables consisted of housing structure attributes and neighborhood environment attributes. Variables in the former included house area (AREA), building age (AGE), square of building age (AGES), number of living rooms (LIVROOM), number of rooms (ROOM), number of bathrooms (BATH), house floor (FLOOR1), type of housing (BUILDING, HUAXIA), and availability of parking lots (PARKING); variables in the latter included the distance to the city center (DISURBA), distance to the nearest metro station (MRT), distance to the nearest railway station (TRAIN), distance to the nearest elementary school (PRIM) and distance to the nearest junior high school (JUNI). In addition, the scale of an urban renewal project (FLAREA) served as a characteristic variable of urban renewal. Empirical analyses were performed in this study through two HLM sub-models, namely the null model (one-way ANOVA with random effects) and the intercepts-as-outcomes regression model with fixed effects. The
Level 1 (individual level) explanatory variables were the variables pertaining to housing structure and neighborhood attributes; the Level 2 (aggregate level) explanatory variables were the variables pertaining to the scale of an urban renewal project.

\subsubsection{Null model}

The null model tests whether differences exist between the mean housing prices in various urban renewal projects without considering any explanatory variables. The main purpose of the null model is to distinguish the intra-group (intra-project) and inter-group (inter-project) variation in housing prices by means of an analysis similar to one-way ANOVA. Since the inter-group effects $\left(u_{0 j}\right)$ are random effects, the model is also dubbed the one-way ANOVA with random effects. The model settings are as follows:

Level 1:

$$
\ln P_{i j}=\beta_{0 j}+r_{i j}, \quad r_{i j} \sim N\left(0, \sigma^{2}\right) .
$$

Level 2:

$$
\beta_{0 j}=\gamma_{00}+u_{0 j}, u_{0 j} \sim N\left(0, \tau_{00}\right),
$$

in which $\ln P_{i t}$ is the $i^{\text {th }}$ housing price in the $j^{\text {th }}$ urban renewal project; $\beta_{0 j}$ is the mean housing price in the $j^{\text {th }}$ project; $r_{i j}$ represents the within-group error term, where the mean value is 0 and the variance has an independent and homogeneous normal distribution. $\gamma_{00}$ is the mean housing price of all projects; $u$ is the inter-group error term, where the mean value is 0 , the variance is $\tau_{00}$, and has an independent and homogeneous normal distribution. $u$ is the difference between the mean housing price in the $j^{\text {th }}$ project and the mean housing price of all projects. Substituting Equation (2) into Equation (1) yields the mixed model.

In HLM analysis, the null model is often used for preliminary analysis as it yields the grand mean housing price. If the validation result of the random component $\left(u_{0 j}\right)$ is significant, then the mean housing prices differs between projects. Therefore, it is necessary to consider the differences between urban renewal projects. We further derived the intra-class correlation coefficient (ICC) to determine the percentage of the variance in housing prices that can be explained by an urban renewal project to the total variance. The ICC is also used to determine whether the HLM approach should be used for analysis.

\subsubsection{Intercepts-as-outcomes model}

The intercepts-as-outcomes model can clarify whether the Level 2 (aggregate level) explanatory variables directly influence the Level 1 (individual level) dependent variable. The Level 1 explanatory variables were chosen in accordance with the hedonic pricing model and included house area (AREA), building age (AGE), square of building age (AGES), number of living rooms (LIVROOM), number of rooms (ROOM), number of bathrooms (BATH), house floor (FLOOR1), type of housing (BUILDING, HUAXIA), availability of parking (PARKING), the distance to the 
city center (DISURBA), the distance to the nearest school (PRIM, JUNI), the distance to the nearest metro station (MRT), and the distance to the nearest railway station (TRAIN). The Level 2 explanatory variable was the scale of an urban renewal project (FLAREA). The variables are described in Table 1; the model settings are as follows:

Level 1:

$\ln P_{i j}=\beta_{0 j}+\beta_{1 j} A R E A_{i j}+\beta_{2 j} A G E_{i j}+\beta_{3 j} A G E S_{i j}+\beta_{4 j} R O O M_{i j}+$

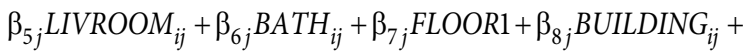
$\beta_{9 j}$ HUAXIA $_{i j}+\beta_{10 j}$ PARKING $+\beta_{11 j}$ DISURBA $_{i j}+\beta_{12 j}$ PRIM $_{i j}+$ $\beta_{13 j} J U N I_{i j}+\beta_{14 j} M R T_{i j}+\beta_{15 j} \operatorname{TRAIN~}_{i j}+r_{i j}$.

Level 2:

$$
\begin{aligned}
& \beta_{0 j}=\gamma_{00}+\gamma_{01} \text { FLAREA }_{j} ; \\
& \beta_{k j}=\gamma_{k 0}, k=1, \ldots, 15 .
\end{aligned}
$$

Substituting Equations (4) and (5) into Equation (3) yields the mixed model.

\subsection{Selection of variables}

The Level 1 explanatory variables consisted of housing structure attributes and neighborhood environment attributes. The Level 2 explanatory variable was the scale of an urban renewal project. The variables are described in Table 1.

Guidry et al. (1999) explored the effects of urban residential land size on residential land prices. The results demonstrated that land size had a positive effect on land price, albeit not statistically significant. Lin (2000) also demonstrated that the land prices increases with an increasing floor area ratio, that is, the larger the floor area permitted for the construction of a building per unit land size, the higher the housing prices. We can further deduce that the scale of an urban renewal project has positive impacts on neighboring housing prices. We used the grand floor area of an urban renewal project to represent

\begin{tabular}{|c|c|c|c|}
\hline Variable & Code & Definition & $\begin{array}{l}\text { Predicted } \\
\text { sign }\end{array}$ \\
\hline \multicolumn{4}{|c|}{ Dependent variable } \\
\hline Logarithm of housing price & $\operatorname{Ln} P_{i j}$ & Logarithm of the price of a housing transaction (including objects) & \\
\hline \multicolumn{4}{|c|}{ Housing structure attributes } \\
\hline House area & AREA & $\begin{array}{l}\text { A continuous variable that refers to the registered building transfer area. } \\
\text { Unit in ping ( } 1 \text { ping is equal to } 35.6 \mathrm{ft}^{2} \text { or } 3.31 \mathrm{~m}^{2} \text { ) }\end{array}$ & + \\
\hline Building age & AGE & $\begin{array}{l}\text { A continuous variable measured from the completion of building } \\
\text { construction to the day of transaction; unit in years }\end{array}$ & - \\
\hline Square of building age & AGES & $\begin{array}{l}\text { The coefficient of the square of building age Observes the linear changes of } \\
\text { the depreciation and is expected to be positive }\end{array}$ & + \\
\hline Number of rooms & ROOM & Number of rooms in a house & + \\
\hline Number of living rooms & LIVROOM & Number of living rooms in a house & + \\
\hline Number of bathrooms & BATH & Number of bathrooms in a house & + \\
\hline Floor number & FLOOR1 & $\begin{array}{l}\text { A dummy variable that represents the registered floor of the house. A value } \\
\text { of } 1 \text { indicates the first floor and } 0 \text { indicates otherwise }\end{array}$ & + \\
\hline Type of housing & $\begin{array}{l}\text { BUILDING } \\
\text { HUAXIA }\end{array}$ & $\begin{array}{l}\text { A dummy variable that consists of apartment buildings, low residential } \\
\text { buildings, and high residential buildings. Apartment buildings serve as } \\
\text { the comparison benchmark and two dummy variables are set. A value of } 1 \\
\text { indicates high residential buildings and } 0 \text { indicates otherwise. A value of } 1 \\
\text { indicates low residential buildings and } 0 \text { indicates otherwise }\end{array}$ & + \\
\hline \multicolumn{4}{|c|}{ Neighborhood environment attributes } \\
\hline Availability of parking lots & PARKING & $\begin{array}{l}\text { A dummy variable that represents whether a housing building has a } \\
\text { parking } \operatorname{lot}(\mathrm{s}) \text {. A value of } 1 \text { indicates yes and } 0 \text { indicates none }\end{array}$ & + \\
\hline Distance to the city center & DISURBA & A continuous variable that indicates the distance to the city center & - \\
\hline $\begin{array}{l}\text { Distance to the nearest } \\
\text { junior high school }\end{array}$ & JUNI & $\begin{array}{l}\text { A continuous variable that indicates the distance to the nearest junior high } \\
\text { school }\end{array}$ & - \\
\hline $\begin{array}{l}\text { Distance to the nearest } \\
\text { elementary school }\end{array}$ & PRIM & $\begin{array}{l}\text { A continuous variable that indicates the distance to the nearest elementary } \\
\text { school }\end{array}$ & - \\
\hline $\begin{array}{l}\text { Distance to the nearest } \\
\text { railway station }\end{array}$ & TRAIN & $\begin{array}{l}\text { A continuous variable that indicates the distance to the nearest railway } \\
\text { station }\end{array}$ & + \\
\hline $\begin{array}{l}\text { Distance to the nearest } \\
\text { MRT station }\end{array}$ & MRT & $\begin{array}{l}\text { A continuous variable that indicates the distance to the nearest MRT } \\
\text { station }\end{array}$ & - \\
\hline $\begin{array}{l}\text { Scale of an urban renewal } \\
\text { project }\end{array}$ & FLAREA & $\begin{array}{l}\text { The grand floor area of an urban renewal project indicates its scale. The } \\
\text { grand floor area is calculated in square meters }\left(\mathrm{m}^{2}\right)\end{array}$ & + \\
\hline
\end{tabular}

Table 1. Description of variables 
its scale. The characteristic variables of Level 2 can also consider the budget of the renewal project, but this information is certainly hard to get. Our research examines the budget items in 23 cases of urban renewal which were in actual execution. Those items included: 1) the construction cost (cost of rebuilding and public facilities); 2) the cost of changing rights or joint construction in agreement (cost of planning, appraisal of real estate, measurement before renewal, compensation for demolition and settlement of land improvement, and cadastral arrangement, which includes the agency fee of trust registration and registration obliteration); 3) loan interests; 4) taxes; 5) management costs (personnel administration, construction project management, sales and administrative expenses, risk management and trust management); 6) cost of transfer of development rights (processing fee and floor area acquisition cost), and 7) the burden cost of changing the urban plan.

\section{Data area and research data}

Urban reconstruction in Taiwan can be traced back to the 1959 China Plaza reconstruction project. At present, the city of Taipei has been promoting urban reconstruction for nearly 60 years. There are three types of demarcation for urban reconstruction projects: general demarcation, prioritized demarcation (Article 6 of the Urban Renewal Act), and prompt demarcation (Article 7 of the Urban Renewal Act). The general demarcation method was applied to projects selected in this study and the reconstruction areas were self-demarcated reconstruction units. In terms of implementation, urban reconstruction projects consist of rights transfer projects and agreement-based joint development projects. In a rights transfer project, land and legally-constructed building owners, other rights holders, or implementers provide land, buildings, other rights, or funds to take part in or implement urban reconstruction. After the completion of an urban reconstruction project, the shares or royalties of the reconstructed buildings or land should be allocated according to the initial proportion of rights or funds provided. In an agreement-based joint development project, a land owner(s) provide land for urban reconstruction, while a construction company provides the funds. After the completion of the project, the shares or royalties of the reconstructed buildings or land are allocated according to the proportion of value agreed by both parties. According to Article 4 of the Urban Renewal Act, there are three forms of urban renewal reconstruction, renovation, and maintenance. In Taiwan, urban reconstruction is the most common form.

In general, the administration process of an urban reconstruction project consists of four stages - demarcation, presentation of a business summary, formulation of a proposal, and rights transfer. In the demarcation stage (first stage), a comprehensive survey and evaluation of the urban reconstruction area is performed according to the urban development condition, residents' willingness, ex- isting society, economic relations, and cultural features of the area. After demarcation, a business summary must be presented (second stage), where the ratio of approval from private land owners and rights holders of legally-construct buildings in the urban reconstruction must be over onetenth. In addition, the ratio of approval for reconstructing existing land areas or the total floor space of a legallyconstructed building must be over one-tenth (Article 10 of the Urban Renewal Act). This procedure can be negated if the ratio of approval exceeds the threshold defined in Article 22 of the Urban Renewal Act. During the formulation of the project proposal (third stage), if the urban reconstruction project was implemented via the rights transfer method (fourth stage), a rights transfer proposal should be implemented and submitted for review when necessary. The rights transfer proposal should be handled together with the urban reconstruction proposal (Article 29 of the Urban Renewal Act). During urban reconstruction, failure to reach a consensus due to rights disputes is not uncommon, therefore rights transfer projects that have been reviewed and are completed were chosen in this study.

Due to the considerable manpower and funds required for urban reconstruction, local governments often encourage private urban reconstruction, under which relevant organizations can submit their self-formulated reconstruction agenda for review by the competent authorities. After approval, the project can either be implemented by the organization themselves or by a reconstruction enterprise commissioned by the rights holders of the land and legally-constructed buildings. Currently, many urban reconstruction projects in Taiwan are privately-funded but are reviewed and supervised by the government. However, disputes often occur when seeking approval from rights holders. In particular, media reports on the Wenlin Yuan controversy had sparked much public interest and disdain with respect urban reconstruction, which had even halted other reconstruction projects. In light of this issue, a draft revision of the Urban Renewal Act was approved on March 2018, in which the ratio of approval from land owners and total land area was increased, and the rights of involved parties during the reconstruction process were guaranteed. Furthermore, the government promulgated the Statute for Expediting Reconstruction of Urban Unsafe and Old Buildings on May 2017, with the hope of expediting the progress of urban reconstruction.

On November 11, 1998, the central government promulgated the Urban Renewal Regulations. On April 20, 2001, the Taipei City Government revised and promulgated the original “Taipei Urban Renewal Implementation Measures" into the "Taipei City Urban Renewal Autonomy Regulations", and subsequent applications were submitted to the Urban Renewal Review Committee for deliberation of the 543 urban renewal business plans, 446 were approved by the municipal government. In these renewal projects, the implementers also donated community activity centers, reserved pedestrian walkways for public passage, and assisted in the development of planned roads. The city government 
will discuss the simplification of the review process, singlewindow operations, and related incentive mechanisms to promote and guide private forces to handle urban renewal (Taipei City Regeneration Office, https://uro.gov.taipei/ News_Content.aspx $? \mathrm{n}=$ B649EEAA7A7E35DB\&sms $=3$ DC F9FD28E559058\&s=F0E9E31078AF60FE).

The housing transaction data used in this study was obtained from two sources. The first is the Taiwan Real Estate Transaction Bulletin on the Gigahouse website. These data sets, dated from January 2008 to December 2009 and from January 2011 to December 2011, are the real estate transaction data of guaranteed performance from various real estate agencies. The second data source is the Ministry of the Interior's actual housing price registration system, from which data covering the period between January 2012 to October 2016 was obtained. The total sample for this period included 19,157 transactions.

Urban renewal cases were retrieved from the publicly available Taipei City urban renewal network database. This study examined 23urban renewal projects that were promoted/reviewed and implemented/completed from 2011 to 2012. The promoted/reviewed projects were based on approvals obtained from governmental authorities, while the implemented/completed projects were based on the acquisition of licenses for construction and use. As shown in Figure 1, the 23 urban reconstruction projects investigated in this study were located in the administrative dis-
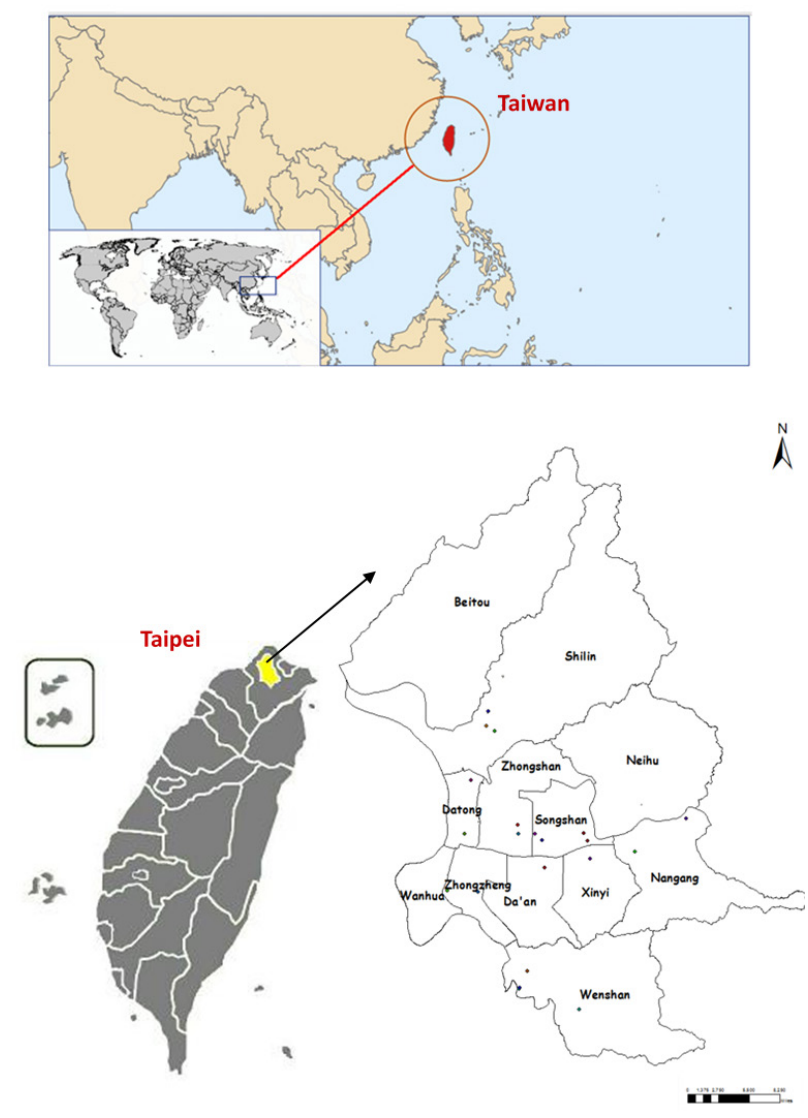

Figure 1. Taipei city urban renewal case map (The dots represent urban renewal projects) tricts of Shilin, Datong, Zhongshan, Zhongzheng, Songshan, Dảan, Xinyi, Wenshan, Neihu, Nangang, and Beitou.

The range of influence of an urban renewal project, as defined by Lee et al. (2017) and Liang et al. (2020) is a distance of 800 meters. About the research on the range of effects for urban renewal, according to the regulations in Article 5 of the Urban Renewal Act, the factor of designating an urban renewal area includes the range of the renewal area, the basic goal and strategics, substantive redevelopment, and designating the renewal units and their standards. Therefore, urban renewal occurs when an area decays; it is a way to redevelop the area as a whole. When self-designating the urban renewal units in urban renewal, it should use whole block planning as a principle. The block means the base surrounded by planning roads or attached to permanent open space, parks, squares, embankments, or rivers. The urban renewal during the process of implementation should put the planned improvement or repair of public facilities in the urban renewal business plan. And after its completion, if enforced in the way of changing rights, the joint burden of public facilities would include seven types of land use: roads for public use, ditches, playgrounds, neighborhood parks, squares, green lands, and parking lots. These have the effect of improving public landscaping and increasing the liveliness in the area of urban renewal. On the other hand, any improvement of the environment that does not have an effect on the renewal area, can still also affect nearby houses. Its range of effects is considered one or two blocks, and a distance of about 800 meters in general.

Zahirovich-Herbert and Gibler (2014) studied the effects of new housing on the prices of neighborhood houses. They set the range of effects at $1 / 4$ mile (400 meters), $1 / 2$ mile ( 800 meters), and 1 mile ( 1600 meters). The empirical results show that the effects of new housing on the prices of neighborhood houses, whether it is positive or negative, are the strongest within a range of $1 / 2$ mile. From the perspective of neighborhood service facilities, the empirical result from Knaap et al. (2001) shows that housing prices increased $36 \%$ within $1 / 2$ mile of a Light Rail Station in Portland. Dai et al. (2016) use the SDID method to study the effects of a Beijing Railway Station on the prices of neighborhood houses. They targeted houses inside the range of 1800 meters as the experimental group, and they used 1800-2000 meters as the control group. The empirical results showed that the station had significant negative effects on house prices inside the range of 200 meters, significant positive effects in the range of 200-800 meters, and no effect on the range of 800-1000 meters. This probably means that the negative effects of issues like noise, pollution, overcrowding, and public safety on housing prices almost disappeared beyond 800 meters. Therefore, he considered the effects of negative externalities of the train station is 800 meters. Given the walking time of ordinary people, Lee et al. (2017) and So et al. (1997) think that the best walking time is 10 minutes, which is the same as a distance of about 800 meters. This research aimed at the discussion of the effects of the neighborhood 
on urban renewal, in order to prevent overextension of the distance to affect the estimation. Therefore, we narrowed the range of effects to within 800 meters. On this basis, 800 meters served as the comparison benchmark of the range of influence in this study, and data of houses located outside the range of influence was removed.

To measure the actual distance from a house to public infrastructure, this study utilized a geographic information system software - Arc GIS version 10.1 to link the data of a house's internal and external characteristics, while integrating the spatial location data of the house and the sample image layer data to construct a database on a house's spatial attributes. This study obtained the addresses of transacted houses from the Taiwan Real Estate Transaction Bulletin. Afterwards, Google Maps and the Taiwan Geospatial One-Stop Portal (TGOS) were employed to convert all sets of house transaction data into spatial data in accordance with the addresses of transacted houses obtained from the Taiwan Real Estate Transaction Bulletin. Afterwards, the location of the sample points of the house transaction spatial data was established in the image layer of Taipei City's administrative districts. After constructing each set of spatial data on housing transactions within the scope of research, the geographic information system software Arc GIS version 10.1 developed by Environmental Systems Research Institute, Inc. (ESRI) was used to overlay the layer of the location of the house transaction spatial data on other layers of relevant public infrastructure, such as MRT stations, railway stations, and schools, with the purpose of calculating the nearest distance from each spatialized housing data to public infrastructure.

\section{Descriptive statistics of samples}

The descriptive statistics of the sample is presented in Table 2. The mean housing price was NT $\$ 26.6933$ million. (1 USD $=27.9$ NTD, January 6,2021$)$ The mean housing area was 43.28 ping. The mean house age was 21.90 years. The mean number of rooms was 2.92 . The mean number of living rooms was 1.85 . The mean number of bathrooms was $1.74 .7 \%$ of houses were located on the first floor. In terms of the type of housing, $44 \%, 30 \%$, and $26 \%$ of houses were high residential buildings, low residential buildings, and apartment buildings, respectively. $37 \%$ of houses had a parking lot(s). The mean distance to the city center was $598.68 \mathrm{~m}$. The mean distance to the nearest elementary school was $365.74 \mathrm{~m}$. The mean distance to the nearest junior high school was $503.63 \mathrm{~m}$. The mean distance to the nearest MRT station was $632.41 \mathrm{~m}$. The mean distance to the nearest railway station was $3276.43 \mathrm{~m}$. The mean grand floor area of urban renewal was $5404.24 \mathrm{~m}^{2}$.

\section{Empirical results}

First, we used the null model to test the variation in the mean house price between various urban renewal projects. As shown in Table 3, with regard to fixed effects, the estimated value of the mean house price $\gamma_{00}$ is 12.095 ; with
Table 2. Descriptive statistics of the sample

\begin{tabular}{|c|c|c|c|c|}
\hline Variable & Mean & S.D. & Minimum & Maximum \\
\hline \multicolumn{5}{|c|}{ Level 1} \\
\hline $\begin{array}{l}\text { PRICE (in } \\
\text { NT } \$ 10,000 \text { units) }\end{array}$ & 2669.33 & 1676.64 & 33.50 & 24500.00 \\
\hline AREA (ping) & 43.28 & 20.07 & 20.00 & 149.83 \\
\hline AGE (years) & 21.90 & 13.47 & 1.00 & 49.98 \\
\hline ROOM & 2.92 & 0.83 & 1 & 6 \\
\hline LIVROOM & 1.85 & 0.40 & 1 & 3 \\
\hline BATH & 1.74 & 0.59 & 1 & 5 \\
\hline FLOOR1 & 0.07 & - & 0 & 1 \\
\hline BUILDING & 0.44 & - & 0 & 1 \\
\hline HUAXIA & 0.30 & - & 0 & 1 \\
\hline PARKING & 0.37 & & 0 & 1 \\
\hline DISTURBA & 598.68 & 261.40 & 0 & 999.99 \\
\hline PRIM & 365.74 & 173.16 & 0 & 1114.77 \\
\hline JUNI & 503.63 & 255.85 & 3.36 & 1436.33 \\
\hline MRT & 632.41 & 482.35 & 3.70 & 2388.18 \\
\hline TRAIN & 3276.43 & 2474.58 & 68.96 & 8842.66 \\
\hline \multicolumn{5}{|c|}{ Level 2} \\
\hline FLAREA & 5404.24 & 4274.29 & 906.62 & 17669.32 \\
\hline
\end{tabular}

Table 3. Null model analysis results

\begin{tabular}{|l|c|c|c|c|}
\hline Fixed effects & Coefficients & $\begin{array}{c}\text { Standardi- } \\
\text { zed errors }\end{array}$ & $t$-ratio & $p$-value \\
\hline$\gamma_{00}$ & $12.095^{* * *}$ & 0.035 & 344.386 & 0.001 \\
\hline $\begin{array}{l}\text { Random } \\
\text { effects }\end{array}$ & $\begin{array}{c}\text { Variance } \\
\text { components }\end{array}$ & $\mathrm{df}$ & $\begin{array}{c}\text { Chi- } \\
\text { square }\end{array}$ & $p$-value \\
\hline$\tau_{00}$ & $0.028^{* * *}$ & 22 & 8861.028 & 0.001 \\
\hline Level-1 $\sigma^{2}$ & 0.061 & & & \\
\hline $\begin{array}{l}\text { Deviance } \\
(-2 \mathrm{LL})\end{array}$ & 933.978 & & & \\
\hline $\begin{array}{l}\text { Number of } \\
\text { estimated } \\
\text { parameters }\end{array}$ & 2 & & & \\
\hline
\end{tabular}

Note: ${ }^{\star}$ indicates $p<0.1,{ }^{* *}$ indicates $p<0.05,{ }^{* *}$ indicates $p<0.01$.

regard to random effects, the estimate value of $\tau_{00}$ is 0.028 , and the statistics of $\chi^{2}$ is 8861.028 , the degree of freedom is $22(J=23$ projects), attaining a $1 \%$ level of significance. These results show that the mean housing price varies significantly between each urban renewal project.

The variance $\tau_{00}$ of the mean urban renewal project price $\beta_{0 j}$ and the individual level intra-group variance $\sigma^{2}$ can be used to calculate the intra-group correlation coefficient $(I C C)$, which is $0.3146(0.028 /(0.028+0.061)=$ 0.3146). According to Cohen's (1998) recommendations, the correlation is strong. This indicates that $31.46 \%$ of the variance in the mean house price is caused by the differences between the urban renewal projects. Thus, it is important to take into account the differences between urban renewal projects. 
The empirical estimation results are presented in Table 4. The estimated coefficient of the grand floor area of urban renewal (FLAREA) was 0.001 and attained a $1 \%$ level of significance. This indicates that the large the scale of an urban renewal project, the larger its effects on neighboring housing prices. Guidry et al. (1999) explored the effects of urban residential land size on residential land prices. The results demonstrated that lot size had a positive effect on land price, albeit not statistically significant. With regard to the housing structure attributes, the symbols of most of the variables were as expected. The estimated coefficient of house area was 0.001 and attained a $1 \%$ level of significance. This indicates that the larger the house area, the higher the price. Freybote and Fruits (2015) demonstrated that house area has a significant and positive effect on housing prices. The estimated coefficient of building age and the square of building age was -0.012 and 0.001 , respectively, and both coefficients attained a $1 \%$ level of significance. This indicates that the higher the building age, the lower the price, and the smaller the price drop. Wilhelmsson (2008) also employed house age and the square of house age as explanatory variables, and showed the negative impacts of house age, in which the impacts decrease with increasing house age. The estimated coefficient of the number of living rooms was 0.024 , and attained a $1 \%$ level of significance. This indicates that the higher the number of living rooms, the higher the housing price. Huang et al. (2010) stated that a living room is an internal layout of a house and the more living rooms a house has, the higher its floor space as well as its price. They expected that the number of living rooms have a positive impact on housing price as well. The estimated coefficient of the number of bathrooms was 0.049 , and attained a $1 \%$ level of significance. This indicates that the higher the number of bathrooms, the higher the housing price. Baltagi and Bresson (2011) demonstrated the positive influence of the number of bathrooms on housing price. The estimated coefficient of floor number was 0.167 , and attained a $1 \%$ level of significance. This indicates that the mean price of houses on the first floor was $16.7 \%$ higher than those that are not on the first floor. Houses on the first floor can also be used for commercial purposes, which explains why they often have higher prices. The estimated coefficients of high residential buildings and low residential buildings was 0.197 and 0.174 , respectively, and coefficients attained a $1 \%$ level of significance. This indicates that the mean price of high residential buildings and low residential buildings was $19.7 \%$ and $17.4 \%$ higher than apartment buildings, respectively. Since high and low residential buildings have many floors, due to safety concerns, housing prices would increase in response to higher construction costs. The estimated coefficient of the number of rooms was -0.016 , and attained a $1 \%$ level of significance. The estimated coefficient of the availability of parking lots was -0.065 and attained a $1 \%$ level of significance. Christiansen et al. (2017) highlighted that houses with parking lots would pose a higher challenge to affordable housing. This also shows that for house buyers who purchased low- to mid-priced houses, buying a house with a parking lot increases affordability, and they would rather buy houses located near a MRT station or those with a larger floor space.

With regard to the neighborhood environment attributes, the estimated coefficient of the distance to the city center -0.001 and attained a $1 \%$ level of significance. This indicates that the closer a house is to the city center, the higher the price. Sunak and Madlener (2016) pointed out that the city center offers more infrastructure, is more developed, and has more commercial and business benefits. Therefore, the closer a house is to the city center, the higher its price. The coefficient of the distance to the nearest elementary school (PRIM) was 0.001 and attained a $1 \%$ level of significance. The coefficient of the distance to the nearest junior high school (JUNI) was -0.001 and attained a $10 \%$ level of significance. This indicates that a junior high school offers school district-related benefits to houses nearby. Proximity to a school not only ensures the accessibility and safety of school children, but also increases recreational space for residents. Therefore, house buyers often consider whether a house is located near a school when they make their purchases. The estimated coefficient of the distance to the nearest MRT station was -0.001 and attained a $1 \%$ level of significance. This indicates that the closer a house is to a MRT station, the higher the price. Many middle-to-low income groups rely on public transportation to commute or travel, and hence a house that is located nearer to a MRT station is often more expensive (Ahlfeldt \& Maennig, 2010). The estimated coefficient of the distance to the nearest railway station (TRAIN) was 0.001 , and attained the $1 \%$ level of significance. Nelson

Table 4. Empirical estimation results

\begin{tabular}{|l|c|c|c|c|}
\hline Fixed effects & & Coefficients & $\begin{array}{c}\text { Standardized } \\
\text { errors }\end{array}$ & $t$-ratio \\
\hline & $\gamma_{00}$ & $11.960^{\star * *}$ & 0.005 & 2203.893 \\
\hline FLAREA & $\gamma_{01}$ & $0.001^{\star * *}$ & 0.001 & 8.803 \\
\hline AREA & $\gamma_{10}$ & $0.001^{\star * *}$ & 0.001 & 6.831 \\
\hline AGE & $\gamma_{20}$ & $-0.012^{* * *}$ & 0.001 & -18.253 \\
\hline AGES & $\gamma_{30}$ & $0.0002^{\star * *}$ & 0.001 & 18.743 \\
\hline ROOM & $\gamma_{40}$ & $-0.016^{* * *}$ & 0.003 & -5.233 \\
\hline LIVROOM & $\gamma_{50}$ & $0.024^{\star * *}$ & 0.005 & 4.312 \\
\hline BATH & $\gamma_{60}$ & $0.049^{* * *}$ & 0.005 & 10.971 \\
\hline FLOOR1 & $\gamma_{70}$ & $0.167^{\star * *}$ & 0.008 & 20.975 \\
\hline BUILDING & $\gamma_{80}$ & $0.197^{\star * *}$ & 0.007 & 29.409 \\
\hline HUAXIA & $\gamma_{90}$ & $0.174^{\star * *}$ & 0.006 & 28.168 \\
\hline PARKING & $\gamma_{100}$ & $-0.065^{\star * *}$ & 0.006 & -10.403 \\
\hline DISURBA & $\gamma_{110}$ & $-0.001^{\star * *}$ & 0.001 & -6.099 \\
\hline PRIM & $\gamma_{120}$ & $0.001^{\star * *}$ & 0.001 & 10.814 \\
\hline JUNI & $\gamma_{130}$ & $-0.001^{\star}$ & 0.001 & -1.775 \\
\hline MRT & $\gamma_{140}$ & $-0.001^{\star * *}$ & 0.001 & -39.312 \\
\hline TRAIN & $\gamma_{150}$ & $0.001^{\star * *}$ & 0.001 & 5.638 \\
\hline
\end{tabular}

Note: ${ }^{\star}$ indicates $p<0.1,{ }^{* *}$ indicates $p<0.05,{ }^{* *}$ indicates $p<0.01$. 
(2004) and Simons and Jaouhari (2004) concurred that while proximity to a railway station offers ease of transportation, a house that is too close to a railway station would be exposed to high noise levels and a high frequency of accidents, which has negative impacts on its price. Comber and Arribas-Bel (2017) pointed out that crime rates could be higher in places near railway stations.

\section{Conclusions and recommendations}

Conventional hedonic pricing models generally use the ordinary least squares (OLS) estimation approach, spatial econometrics or other methods, in which data with different hierarchical characteristics are confined to a single level for data processing, and the estimation of hierarchical problems are not taken into account. Since housing units are nested within various urban renewal projects, the impacts of an urban renewal project on neighboring housing prices should take into account the intrinsic differences of the project on neighboring housing prices. Hierarchical linear modeling (HLM) was employed for data analysis. Compared to the conventional ordinary least squares (OLS) models, HLM can further provide deeper insights into the relationships between housing prices and the characteristics of urban renewal projects.

Arribas et al. (2016) think that OLS couldn't solve the within-group correlation of datasets on housing prices or the correlation between housing prices and neighborhood environment. Housing information belongs to the nested structure. If we use single-level OLS, it will lead to inference errors. In past research, the paper by Lee et al. (2017) and Liang et al. (2020) adopted HLM model to study the effects of urban renewal on housing prices, and Liang et al. (2020) adopted spatial econometrics for their research. They both neglected the hierarchical structure of housing information. This will generate bias in the modeling estimation. In addition, it will not be possible to observe the cross-level influence of the effects of urban renewal. In this study, the HLM we adopted considered hierarchical structures, which can provide more information for the estimation and the result will be more accurate (Arribas et al., 2016). By using HLM analysis, we can understand how variations in individual houses affect Level 1 and how (the explained variation) urban renewal affects Level 2.

The empirical results showed that the mean housing price varies significantly between each urban renewal project. $31.46 \%$ of the variance in the mean house price is caused by the differences between the urban renewal projects. In this regard, it is important to take into account the differences between urban renewal projects when examining the impacts of urban renewal projects on neighboring housing prices. The estimated coefficient of the grand floor area of urban renewal (FLAREA) had a positive value and attained a $1 \%$ level of significance. This indicates that the larger the scale of an urban renewal project, the larger its effects on neighboring housing prices. Our findings show that urban renewal projects of different scales have different impacts on neighboring housing prices. Previously, we also used 500 meters as the range of effects for estimation, but there was no significant difference in the results.

Subsequent research could include other features of urban renewal for analysis to allow for a more thorough analysis on the impacts of urban renewal on neighboring housing prices. In addition, we suggest examining whether the features of urban renewal projects moderate the impacts of housing features on housing prices, that is, whether moderating effects exist between the aggregatelevel variables and the individual-level variables.

Level 1 of this research is the attributes of the neighborhood environment of the individual house (such as the distances to downtown, to schools, to the nearest MRT station, to the nearest train station). This means that the attributes of the neighborhood environment are variables of Level 1. If thinking about taking "urban renewal projects are nested within various neighborhood areas" for design, it will set the neighborhood environment as the third level of variables. If you are thinking about three levels of analysis, it means the individual house is nested in cases of urban renewal, and cases of urban renewal are nested in the neighborhood. Now we must deal with the problem of measuring the neighborhood-how to divide the neighborhood-which was unclear in Taiwan. This time the variables that represent the neighborhood environment of each neighborhood are the distance of the neighborhood to downtown, to schools, to the nearest MRT station, to the nearest train station. If these are the variables of the neighborhood environment, it creates the problem of overlapping variables of the neighborhood environment from Level 1. Analysis on three levels is complicated, and for Level 3 we must consider how to represent the characteristic variables of Level 3. This analysis will be more complicated than ever. However, if we consider taking Level 1 as the individual house, Level 2 as the cases of urban renewal, and Level 3 as the administrative area, this is more feasible, and we suggest this should also be the direction of future research.

\section{Acknowledgements}

Thanks to Miss Dai-juan Liu for helping to draw Figure 1.

\section{References}

Ahlfeldt, G. M., \& Maennig, W. (2010). Impact of sports arenas on land values: evidence from Berlin. The Annals of Regional Science, 44(2), 205-227. https://doi.org/10.1007/s00168-008-0249-4

Arribas, I., García, F., Guijarro, F., Oliver, J., \& Tamošiūniene, R. (2016). Mass appraisal of residential real estate using multilevel modelling. International Journal of Strategic Property Management, 20(1), 77-87.

https://doi.org/10.3846/1648715X.2015.1134702

Baltagi, B. H., \& Bresson, G. (2011). Maximum likelihood estimation and Lagrange multiplier tests for panel seemingly unrelated regressions with spatial lag and spatial errors: an application to hedonic housing prices in Paris. Journal of Urban Economics, 69(1), 24-42.

https://doi.org/10.1016/j.jue.2010.08.007 
Basu, S., \& Thibodeau, T. G. (1998). Analysis of spatial autocorrelation in house prices. Journal of Real Estate Finance and Economics, 17(1), 61-85.

https://doi.org/10.1023/A:1007703229507

Brown, K., \& Uyar, B. (2004). A hierarchical linear model approach for assessing the effects of house and neighborhood characteristics on housing prices. Journal of Real Estate Practice and Education, 7(1), 15-24.

https://doi.org/10.1080/10835547.2004.12091603

Chang, Y. S., Lin, Y. J., Liu, L. L., Shiue, M. J., \& Wheatley, C. M. (2018). The use of hierarchical linear modeling to address lack-of-independence in empirical auditing research. European Accounting Review, 27(1), 185-196.

https://doi.org/10.1080/09638180.2016.1248459

Chau, K. W., \& Wong, S. K. (2014). Externalities of urban renewal: a real option perspective. Journal of Real Estate Finance and Economics, 48(3), 546-560.

https://doi.org/10.1007/s11146-013-9418-Z

Chau, K. W., Wong, S. K., Leung, A. Y. Y., \& Yiu, C. Y. (2003). Estimating the value enhancement effects of refurbishment. Facilities, 21(1/2), 13-19. https://doi.org/10.1108/02632770310460504

Chen, T. Y., \& Jou, R. C. (2019). Using HLM to investigate the relationship between traffic accident risk of private vehicles and public transportation. Transportation Research Part A: Policy and Practice, 119, 148-161. https://doi.org/10.1016/j.tra.2018.11.005

Chien, S. P., \& Wu, H. K. (2020). Examining influences of science teachers' practices and beliefs about technology-based assessment on students' performances: a hierarchical linear modeling approach. Computers \& Education, 157, 103986. https://doi.org/10.1016/j.compedu.2020.103986

Christiansen, P., Engebretsen, Ø., Fearnley, N., \& Hanssen, J. U. (2017). Parking facilities and the built environment: impacts on travel behaviour. Transportation Research Part A: Policy and Practice, 95, 198-206.

https://doi.org/10.1016/j.tra.2016.10.025

Cohen, J. (1998). Statistical power analysis for the behavioral sciences. Lawrence Erlbaum Associates.

Comber, S., \& Arribas-Bel, D. (2017). "Waiting on the train": the anticipatory (causal) effects of Crossrail in Ealing. Journal of Transport Geography, 64, 13-22.

https://doi.org/10.1016/j.jtrangeo.2017.08.004

Dai, X., Bai, X., \& Xu, M. (2016). The influence of Beijing rail transfer stations on surrounding housing prices. Habitat International, 55, 79-88.

https://doi.org/10.1016/j.habitatint.2016.02.008

Do, M. H., \& Park, S. C. (2018). New rural development and hierarchical governance in Vietnam: impacts of government support on rural households' income using a hierarchical linear modelling. AGRIS on-line Papers in Economics and Informatics, 10(4), 3-15. https://doi.org/10.7160/aol.2018.100401

Freybote, J., \& Fruits, E. (2015). Perceived environmental risk, media, and residential sales prices. Journal of Real Estate Research, 37(2), 217-244. https://doi.org/10.1080/10835547.2015.12091413

Guidry, K., Shilling, J. D., \& Sirmans, C. F. (1999). Land-use controls, natural restrictions, and urban residential land prices. Review of Regional Studies, 29(2), 105-114. https://doi.org/10.52324/001c.8828

Huang, B., Wu, B., \& Barry, M. (2010). Geographically and temporally weighted regression for modeling spatio-temporal variation in house prices. International Journal of Geographical Information Science, 24(3), 383-401.

https://doi.org/10.1080/13658810802672469
Hyra, D. (2008). The new urban renewal: the economic transformation of Harlem and Bronzeville. University of Chicago Press.

Jones, K., \& Bullen, N. (1994). Contextual models of urban house prices: a comparison of fixed-and random-coefficient models developed by expansion. Economic Geography, 70(3), 252-272. https://doi.org/10.2307/143993

Jones, P. (2008). Different but the same? Post-war slum clearance and contemporary regeneration in Birmingham, UK. City, 12(3), 356-371. https://doi.org/10.1080/13604810802478987

Knaap, G. J., Ding, C., \& Hopkins, L. D. (2001). Do plans matter? The effects of light rail plans on land values in station areas. Journal of Planning Education and Research, 21(1), 32-39. https://doi.org/10.1177/0739456X0102100103

Lai, L. W., Chau, K. W., \& Cheung, P. A. C. (2018). Urban renewal and redevelopment: social justice and property rights with reference to Hong Kong's constitutional capitalism. Cities, 74, 240-248. https://doi.org/10.1016/j.cities.2017.12.010

Lee, C. C. (2010). The impact of facilities of leisure and sports on housing prices in Taiwan: an application of hierarchical linear modeling. Journal of Real Estate Practice and Education, 13(2), 159-175.

https://doi.org/10.1080/10835547.2010.12091674

Lee, C. C., Liang, C. M., \& Chen, C. Y. (2017). The Impact of urban renewal on neighborhood housing prices in Taipei: an application of the difference-in-difference. Journal of Housing and the Building Environment, 32(3), 407-428. https://doi.org/10.1007/s10901-016-9518-1

Liang, C. M., Lee, C. C., \& Yong, L. R. (2020). Impacts of urban renewal on neighborhood housing prices: predicting response to psychological effects. Journal of Housing and the Built Environment, 15, 191-213. https://doi.org/10.1007/s10901-019-09673-z

Lin, T. T. (2000). Land prices and floor area ratios [Master's thesis]. National Cheng Kung University, Graduate Institute of Urban Planning, Tainan City.

Mori, C. (2017). Social housing and urban renewal in Tokyo: from post-war reconstruction to the 2020 Olympic Games. In P. Watt \& P. Smets (Eds.), Social housing and urban renewal (pp. 277-309). Emerald Publishing Limited. https://doi.org/10.1108/978-1-78714-124-720171008

Musakwa, W., \& Niekerk, A. V. (2013). Implications of land use change for the sustainability of urban areas: a case study of Stellenbosch, South Africa. Cities, 32, 143-156. https://doi.org/10.1016/j.cities.2013.01.004

Nelson, J. P. (2004). Meta-analysis of airport noise and hedonic property values. Journal of Transport Economics and Policy, 38(1), 1-27.

Pov, S., Kawai, N., \& Murakami, R. (2020). Identifying causes of lower secondary school dropout in Cambodia: a two-level hierarchical linear model. International Journal of Inclusive Education, 1-14. https://doi.org/10.1080/13603116.2020.1735542

Rosenthal, S. S. (2008). Old homes, externalities, and poor neighborhoods a model of urban decline and renewal. Journal of Urban Economics, 63(3), 816-840. https://doi.org/10.1016/j.jue.2007.06.003

Simons, R. A., \& Jaouhari, E. A. (2004). The effect of freight railroad tracks and train activity on residential property values. Appraisal Journal, 72(3), 223-233.

Simons, R., Quercia, R., \& Levin, I. (1998). The value impact of new residential construction and neighborhood disinvestment on residential sales price. Journal of Real Estate Research, 15(2), 147-161. https://doi.org/10.1080/10835547.1998.12090921 
So, H. M., Tse, R. Y., \& Ganesan, S. (1997). Estimating the influence of transport on house prices: evidence from Hong Kong. Journal of Property Valuation and Investment, 15(1), 40-47. https://doi.org/10.1108/14635789710163793

Sunak, Y., \& Madlener, R. (2016). The impact of wind farm visibility on property values: a spatial difference-in-differences analysis. Energy Economics, 55, 79-91.

https://doi.org/10.1016/j.eneco.2015.12.025

Uitermark, J., \& Loopmans, M. (2013). Urban renewal without displacement? Belgium's 'housing contract experiment' and the risks of gentrification. Journal of Housing and the Built Environment, 28(10), 157-166. https://doi.org/10.1007/s10901-012-9299-0

Uyar, B., \& Brown, K. (2007). Neighborhood affluence, schoolachievement scores, and housing prices: cross-classified hierarchies and HLM. Journal of Housing Research, 16(2), 97-116. https://doi.org/10.1080/10835547.2007.12091980

Wang, H., Shen, Q., Tang, B. S., \& Skitmore, M. (2013). An integrated approach to supporting land-use decisions in site redevelopment for urban renewal in Hong Kong. Habitat International, 38, 70-80. https://doi.org/10.1016/j.habitatint.2012.09.006

Wilhelmsson, M. (2008). House price depreciation rates and level of maintenance. Journal of Housing Economics, 17(1), 88-101. https://doi.org/10.1016/j.jhe.2007.09.001
Xu, W., Jin, X., Liu, J., \& Zhou, Y. (2021). Analysis of influencing factors of cultivated land fragmentation based on hierarchical linear model: a case study of Jiangsu Province, China. Land Use Policy, 101, 105119. https://doi.org/10.1016/j.landusepol.2020.105119

Yalpir, S., \& Bayrak, E. (2017). Real estate valuation in urban regeneration application: case study of Konya. Selcuk University Journal of Engineering, Science and Technology, 5(1), 96-103. https://doi.org/10.15317/Scitech.2017.73

Yau, Y., Wong, S. K., Cheung, K. C., Chau, K. W., \& Ho, D. C. W. (2006). An empirical study on the neighbourhood effect of refurbishment [Conference presentation]. Proceedings from the Pacific Rim Real Estate Society Conference 2006. Pacific Rim Real Estate Society.

Zahirovich-Herbert, V., \& Gibler, K. M. (2014). The effect of new residential construction on housing prices. Journal of Housing Economics, 26, 1-18. https://doi.org/10.1016/j.jhe.2014.06.003

Zheng, X., Li, J. X., Zheng, L., \& Lv, J. (2020). Multi-owned property, urban renewal and neighborhood property value externalities: revisiting the Hong Kong case. Cities, 107, 102915. https://doi.org/10.1016/j.cities.2020.102915

Zient, J., Zient, E. N., \& Sirmans, G. S. (2008). Determinants of house prices: a quantile regression aggregation bias. Journal of Real Estate Finance and Economics, 37(4), 317-333. https://doi.org/10.1007/s11146-007-9053-7 